\title{
PENGEMBANGAN E-MODUL PADA MATA PELAJARAN PEMODELAN PERANGKAT LUNAK KELAS XI DENGAN MODEL PROBLEM BASED LEARNING DI SMK NEGERI 2 TABANAN
}

\author{
I Gede Agus Saka Prasetya'), I Made Agus Wirawan'1), \\ I Gede Partha Sindu1) \\ Fakultas Teknik dan Kejuruan, Universitas Pendidikan Ganesha (penulis 1) \\ email: prasetyasaka69@gmail.com \\ Fakultas Teknik dan Kejuruan, Universitas Pendidikan Ganesha (penulis 2) \\ email: imade.aguswirawan@undiksha.ac.id \\ Fakultas Teknik dan Kejuruan, Universitas Pendidikan Ganesha (penulis 3) \\ email: partha.sindu@undiksha.ac.id
}

\begin{abstract}
Abstrak
Tujuan penelitian ini (1) Untuk menghasilkan sebuah produk E-Modul pada Mata Pelajaran Pemodelan Perangkat Lunak Kelas XI dengan Model Problem Based Learning di SMK Negeri 2 Tabanan. (2) Untuk mengetahui respon siswa dan guru terhadap Pengembangan E-Modul Pada Mata Pelajaran Pemodelan Perangkat Lunak Kelas XI dengan Model Problem Based Learning di SMK Negeri 2 Tabanan.

Metode penelitian yang digunakan dalam penelitian ini adalah research and development (R\&D), dengan model pengembangan ADDIE. Subjek penelitian ini yaitu siswa kelas XI Rekayasa Perangkat Lunak dan guru mata pelajaran Pemodelan Perangkat Lunak di SMK Negeri 2 Tabanan tahun ajaran 2016/2017. Untuk mengetahui respon siswa dan guru terhadap E-Modul diperoleh dengan menggunakan metode angket.

Hasil penelitian menunjukkan bahwa: 1) Produk yang dihasilkan telah memenuhi uji kevalidan, content dan uji efektifitas. 2) Hasil analisis data respon siswa menunjukkan bahwa persentase siswa yang memberikan respon sangat baik sebesar $84,00 \%$, persentase siswa yang memberikan respon baik sebesar $16,00 \%$, dan tidak ada siswa yang memberikan respon cukup, kurang, maupun sangat kurang. Sedangkan hasil analisis data respon guru menunjukkan bahwa persentase guru yang memberikan respon sangat baik.
\end{abstract}

Kata-kata kunci: E-Modul, Pemodelan Perangkat Lunak, Problem Based Learning, Blended Learnig

\section{Abstract}

The aims of this research were (1) to make a product of E-Modulon software engineering subjects of eleventh grade students by using Problem Based Learning at SMK Negeri 2 Tabanan, (2) to know the students and teachers' responses toward the development of E-Modulon the software engineering subjects of eleventh grade students by using Problem Based Learning at SMK Negeri 2 Tabanan.

The research method used in this research was Research and Development (R\&D) using ADDIE development model. The subject of this research was eleventh grade students of Software Engineering program along with their teacher of software engineering subject at SMK Negeri 2 Tabanan in the academic year of 2016/2017. Questionnaire was used in order to know the students and teachers' responses.

The results of this research are: 1) the product already past the validation test,content and evectifnes. 2) the result of data analysis of students responses show that $84.00 \%$ of students gives "sangat baik", the percentage of students who give "baik" is $16.00 \%$, and none of the students gives "cukup, "kurang", or "sangat kurang". Meanwhile, the result of data analysis of teachers' give a very good response.

Keywords: E-Modul, Software Engineering, Problem Based Learning Model, Blended Learnig 


\section{PENDAHULUAN}

Teknologi, informasi, dan komunikasi (TIK), memiliki potensi yang sangat besar sebagai sarana atau alat untuk mengembangkan keterampilan dalam proses pembelajaran. Teknologi akan membantu mengembangkan semua jenis keterampilan berpikir mulai dari tingkat yang paling mendasar hingga tingkat keterampilanberpikir kritis. Tidak diragukan lagi teknologi memberikan peran yang sangat penting untuk kemajuan yang pendidikan (Aunurrahman, 2009).

SMK atau Sekolah Menengah Kejuruan adalah salah satu bentuk satuan pendidikan formal yang menyelenggarakan pendidikan kejuruan pada jenjang pendidikan menengah sebagai lanjutan dari SMP/MTs atau bentuk lain yang sederajat atau lanjutan dari hasil belajar yang diakui sama/setara SMP/MTs. Siswa dengan lulusan dari SMK juga bisa meneruskan jenjang pendidikan lebih tinggi yaitu Perguruan Tinggi dengan bekal yang telah ia dapatkan dari SMK (Tatan, Z, 2012).

Demikian juga dengan SMK Negeri 2 Tabanan yang terletak di Jalan Wisnu Marga, Kecamatan Marga, Kabupaten Tabanan ini merupakan Sekolah Menengah Kejuruan di Bali yang berpegang teguh pada visi "Terwujudnya sikap dan perilaku kewiraswastaan melalui penerapan pola manajemen partisipatif yang berorientasi pada pendayagunaan teknologi informasi yang berakses global". Melalui hasil observasi yang dilakukan, SMK Negeri 2 Tabanan membuka 2 bidang keahlian bagian teknologi informasi. Salah satunya adalah program keahlian Rekayasa Perangkat Lunak (RPL). Program keahlian RPL juga sangat banyak memiliki cabang ilmu yang harus ditempuh diantaranya pada mata pelajaran Pemodelan Perangkat Lunak. Mata pelajaran Pemodelan Perangkat Lunak ini ditempuh pada saat kelas XI. Mata pelajaran Pemodelan Perangkat Lunak kelas XI bertujuan untuk memberikan pemahaman dan penguasaan pengetahuan serta keterampilan untuk membuat rancangan aliran data sesuai dengan konsep pelajaran Pemodelan Perangkat Lunak.
Proses pembelajaran Pemodelan Perangkat Lunak menekankan pada kemandirian siswa, serangkaian pembelajaran tersebut sangatlah padat dan memerlukan sebuah alat pendukung pembelajaran yang memadai. Penggunaan sumber belajar melalui buku juga menyebabkan pembelajaran lebih monoton dan lebih terfokus ke guru. Masalah ini menyebabkan pembelajaran menjadi kurang efektif dan kurang menyenangkan, untuk itu diperlukan sebuah bahan ajar dengan tujuan siswa mampu belajar mandiri. Permasalahan lain yang didapat yaitu pembelajaran dilakukan bersumber kepada internet, belum pernah tersedianya e-modul di SMK Negeri 2 Tabanan, dan siswa belum sepenuhnya tertarik mengikuti proses pembelajaran.

Berdasarkan permasalahan tersebut maka perlu dikembangkan sebuah media pembelajaran. Penggunaan media belajar yang refresentatif telah meningkatkan minat belajar siswa yang berdampak pada hasil belajar. Media pembelajaran yang ada yaitu menggunakan modul. Mengikuti perkembangan zaman yang ada, modul pembelajaran kini sudah bisa berpindah ke dalam bentuk e-modul.

Permasalahan kedua yaitu kognitif siswa yang berbeda menuntut dikembangkannya e-modul yang sesuai dengan keadaan dan permasalah yang terjadi di kelas.

Berdasarkan permasalahan yang telah diuraikan maka peneliti bermaksud mengembangkan e-modul yang berjudul "Pengembangan E-modul pada Mata Pelajaran Pemodelan Perangkat Lunak Kelas XI dengan Model Problem Based Learning di SMK Negeri 2 Tabanan"

\section{Mata Pelajaran Pemodelan Perangkat Lunak}

Pemodelan Perangkat Lunak merupakan salah satu mata pelajaran produktif program keahlian RPL di SMK Negeri 2 Tabanan. Materi yang nantinya dimasukkan dalam e-moduleadalah materi dalam mata pelajaran Pemodelan Perangkat Lunak. Pemodelan Perangkat Lunak merupakan salah satu mata pelajaran wajib paket keahlian RPL yang harus dicapai oleh siswa SMK. Tujuan 
dalam mempelajari materi Pemodelan Peranglat Lunak agar siswa dapat memiliki keterampilan, sikap dan kompetensi yang berkaitan dengan Konsep Pemodelan Perangkat Lunak, Model proses pengembangan perangkat lunak, Rekayasa kebutuhan perangkat lunak, Diagram alur data (DFD, Diagram hubungan antar entitas (ERD), Antar muka pengguna (user interface), Arsitektur perangkat lunak , Pemodelan sistem berorientasi obyek (UML), Kebutuhan sistem berbasis obyek, Alur kerja sistem berorientasi obyek, Hubungan antar kelas, Interaksi antar obyek, Siklus hidup obyek, Hubungan antar Komponen, Dokumen laporan pengembangan sistem berorientasi obyek.

\section{Modul Ajar}

Menurut Mulyasa (dalam Wijayanto, 2014) Modul adalah suatu cara pengorganisasian materi pelajaran yang memperhatikan fungsi pendidikan. Strategi pengoperasian materi pembelajaran mengandung squencing yang mengacu pada pembuatan urutan penyajian materi pelajaran, dan synthesizing yang mengacu pada upaya untuk menunjukkan kepada pembelajaran keterkaitan antara fakta, konsep, prosedur dan prinsip yang terkandung dalam materi pembelajaran, yaitu: (1) informasi verbal, (2) keterampilan intelektual, (3) strategi kognitif, (4) sikap, dan (5) keterampilan motorik. Strategi pengorganisasian materi pembelajaran terdiri dari tiga tahapan proses berpikir, yaitu (1) pembentukan konsep, (2) intepretasi konsep, dan (3) aplikasi prinsip. Strategi-strategi tersebut memegang peranan sangat penting dalam mendesain pembelajaran. Kegunaannya dapat membuat mahasiswa lebih tertarik dalam belajar, mahasiswa otomatis belajar bertolak dari prerequisites, dan dapat meningkatkan hasil belajar (Santyasa, 2009).Selain itu modul mrupakan suatu bahan ajar yang d kemas secara utuh dan sistmatis, di dalamnya dimuat seperangkat pengalaman belajar yang terencana dan didesain untuk membantu peserta didik menguasai tujuan belajar yang spesifik (Depdiknas, 2008). Modul berfungsi sebagai sarana belajar yang besifat mandiri, sehingga peserta didik mampu belajar sesuai dengan kecepatan masingmasing.

\section{E-modul (Modul Elektronik)}

Modul elektronik merupakan versi elektronik dari sebuah modul yang sudah dicetak yang dapat dibaca pada komputer dan dirancang dengan software yang diperlukan. E-modul merupakan alat atau sarana pembelajaran yang berisi materi, metode, batasan-batasan dan cara mengevaluasi yang dirancang secara sistematis dan menarik untuk mencapai kompetensi yang diharapkan sesuai dengan tingkat kompleksitasnya secara elektronik.

Menurut Cecep, K \& Bambang, S (dalam Wiyoko, 2014) menyatakan bahwa media elektronik yang dapat diakses oleh siswa mempunyai manfaat dan karakteristik yang berbeda-beda. Jika ditinjau dari manfaatnya media elektronik sendiri dapat menjadikan proses pembelajaran lebih menarik, interaktif, dapat dilakukan kapan dan dimana saja serta dapat meningkatkan kualitas pembelajaran. Sebagaimana penelitian yang dilakukan oleh Salsabila (2013) terkait dengan media elektronik, menunjukkan bahwa penggunaan media pembelajaran berupa modul elektronik dapat meningkatkan motivasi belajar siswa dengan persentase rata-rata sebesar $89 \%$. Selain itu, modul elektronik mempunyai karakteristik berupa ukuran file yang relatif kecil sehingga dapat disimpan dalam flashdisk, mudah untuk dibawa, bisa digunakan secara off-line, dapat dipelajari kapan dan dimana saja asalkan ada komputer/laptop. Kemudian adanya link yang membantu untuk menelusuri materi secara linier maupun non linier sehingga mengarahkan siswa menuju informasi tertentu. Di dalam modul elektronik juga dilengkapi animasi dan simulasi praktikum serta siswa dapat mengetahui ketuntasan belajar melalui evaluasi mandiri yang interaktif. Karakteristik modul elektronik seperti di atas perlu dimiliki oleh siswa, karena modul elektronik berpotensi meningkatkan motivasi belajar siswa. Selain untuk meningkatkan motivasi belajar siswa modul elektronik juga sangan mudah dibawa, modul elektronik hanya disimpan di PC atau laptop dan tidak memerlukan biaya 
yang sangat mahal. Pemahaman terhadap media e-modul memerlukan pemahaman awal definisi dari dua hal yaitu tentang media dan e-Modul. Association of Education and Commmunication Technology (AECT) (dalam Fausih, 2015) memberi batasan tentang media sebagai segala bentuk dan saluran yang digunakan untuk menyampaikan pesan atau informasi. Pada definisi ahli yang berbeda pula mendefinisikan media adalah berbagai jenis komponen dalam lingkungan siswa yang dapat merangsang siswa untuk belajar. Briggs mengatakan bahwa media adalah alat untuk memberikan rangsangan bagi siswa supaya proses belajar terjadi, hal ini dikemukakan oleh Gagne.

\section{Model Pembelajaran Project Based Learning}

PBL dapat diartikan sebagai suatu pendekatan pembelajaran yang menggunakan masalah dunia nyata sebagai suatu konteks bagi siswa untuk belajar tentang cara berpikir kritis dan keterampilan pemecahan masalah, serta untuk memperoleh pengetahuan dan konsep yang esensial dari materi kuliah atau materi pelajaran.

Landasan teori Problem Based Learning adalah kolaboratifisme, suatu pandangan yang berpendapat bahwa guru menyusun pengetahuan dengan cara membangun penalaran dari semua pengetahuan yang sudah dimlikinya dan dari semua yang diperoleh sebagai hasil kegiatan berinteraksi dengan sesama individu.

Hal tersebut juga menyiratkan bahwa proses pembelajaran berpindah dari transfer informasi fasilitator guru ke proses konstruksi pengetahuan yang sifatnya sosial dan individual. Menurut paham kosntruktivisme, manusia hanya dapat memahami melalui segala sesuatu yang dikonstruksinya sendiri.

Berdasarkan teori yang dikembangkan Barrow dan Min Liu (dalam

Lidinillah, 2013), menjelaskan karakteristik dari Problem Based Learning, yaitu:

1. Learning is student-centered

Proses pembelajaran dalam PBL lebih menitikberatkan kepada siswa sebagai orang belajar. Oleh karena itu, PBL didukung juga oleh teori konstruktivisme dimana siswa didorong untuk dapat mengembangkan pengetahuannya sendiri.

2. Authentic problems form the organizing focus for learning

Masalah yang disajikan kepada siswa adalah masalah yang otentik sehingga siswa mampu dengan mudah memahami masalah tersebut serta dapat menerapkannya dalam kehidupan profesionalnya nanti.

3. New information is acquired through selfdirected learning

Dalam proses pemecahan masalah mungkin saja siswa belum mengetahui dan memahami semua pengetahuan prasyaratnya, sehingga siswa berusaha untuk mencari sendiri melalui sumbernya, baik dari buku atau informasi lainnya.

4. Learning occurs in small groups

Agar terjadi interaksi ilmiah dan tukar pemikiran dalam usaha membangun pengetahuan secara kolaborative, maka PBL dilaksakan dalam kelompok kecil. Kelompok yang dibuat menuntut pembagian tugas yang jelas dan penetapan tujuan yang jelas.

5. Teachers act as facilitators

Pada pelaksanaan Problem Based Learning, guru hanya berperan sebagai fasilitator. Namun, walaupun begitu guru harus selalu memantau perkembangan aktivitas siswa dan mendorong siswa agar mencapai target yang hendak dicapai.

Menurut Fogarty (dalam Santyasa, 2012) pembelajaran berbasis masalah dijalankan dengan 8 langkah yaitu: (1) menemukan masalah; (2) mendefinisikan masalah; (3) mengumpulkan fakta-fakta; (4) menyusun dugaan sementara; (5) menyelidiki; (6) menyempurnakan permasalahan yang telah didefinisikan; (7) menyimpulkan alternatif-alternatif pemecahan secara kolaboratif; dan (8) menguji solusi permasalahan.

\section{Kerangka Berpikir}

Proses pembelajaran rekayasa perangkat lunak di keas XI RPL SMK Negeri 2 Tabanan menunjukan bahwa 
terdapat beberapa kendala terkait dengan Metode mengajar dan media pembelajaran yang merupakan dua unsur yang amat penting. Kedua aspek ini saling berkaitan. Pemilihan salah satu metode mengajar tertentu dapat mempengaruhi jenis media pembelajaran yang sesuai, meskipun masih ada berbagai aspek lain yang harus diperhatikan dalam memilih media, antara lain tujuan pembelajaran, jenis tugas dan respon yang diharapkan siswa kuasai setelah pembelajaran berlangsung, dan konteks pembelajaran termsuk karakteristik siswa. Meskipun demikian, dapat dikatakan bahwa salah satu fungsi utama media pembelajaran adalah sebagai alat bantu mengajar, selain itu pengaruh guru dalam memberikan materi juga sangat penting dalam proses pembelajaran.

Pada kenyataanya observasi yang di lakukan pada tanggal 11 januari 2016 di sekolah mata pemodelan perangkat lunak pada jurusan RPL di SMK N 2 Tabanan di temukan masalah sebagai berikut :

1. Terbatasnya sumber dan media yang berkaitan dengan materi Pemodelan Perangkat Lunak.Dilihat dari hasil nilai Ulangan Akhir Semester (UAS) siswa, terlihat dari siswa hanya sedikit siswa yang berhasil mencapai Kriteria Ketuntasan Minimal (KKM)

2. Kenyataan bahwa guru sebagai pengajar masih banyak yang menggunakan metode dan media konvensional dalam mengajarkan materi pembelajaran.

3. Berdasarkan hasil angket yang diberikan ke siswa, karakteristik siswa lebih cenderung memiliki sikap yang kurang tanggap/aktif di kelas (dokumentasi dan angket terlampir).

4. Kurikulum yang diterapkan di SMK Negeri 2 Tabanan adalah Kurikulum 2013. Penerapan kurikulum 2013 di SMK Negeri 2 Tabanan baru berjalan selama 1 tahun sehingga banyak media yang harus diperbaharui untuk menyesuaiakan dengan kurikulum 2013. Berdasarkan Permendikbud Nomor 65 Tahun 2013 tentang Standar Proses.

Skema kerangka berpikir dalam melaksanakan kegiatan penelitian secara sederhana disajikan pada gambar di bawah ini.

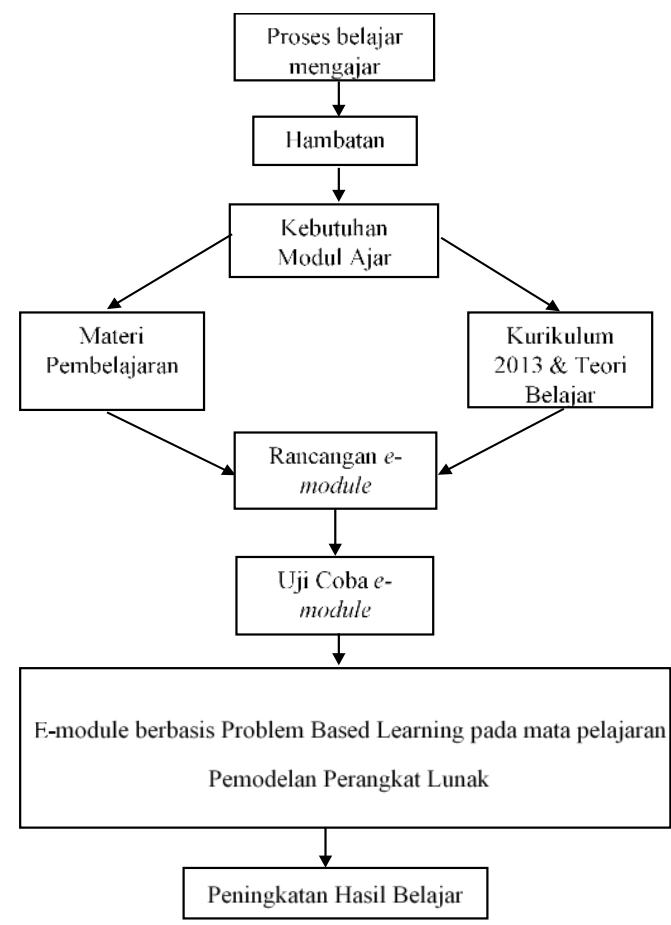

Gambar 1. Kerangka Berpikir

\section{METODE}

Penelitian ini merupakan jenis penelitian pengembangan atau yang sering disebut Research and Development ( $\mathrm{R}$ \& D). Penelitian ini bertujuan untuk mengembangkan sebuah e-modul khususnya pada mata pelajaran Pemodelan Perangkat Lunak. Pengembangan research and development merupakan metode penelitian yang digunakan untuk menghasilkan produk tertentu, menguji keefektifan produk tersebut (Sugiyono, 2014). Model pengembangan yang digunakan dalam penelitian ini yaitu model pengembangan ADDIE. ADDIE merupakan salah satu model desain pembelajaran yang dikembangkan oleh Reiser dan Mollenda pada tahun 1990-an yang salah satu fungsinya menjadi pedoman dalam membangun perangkat dan infrastruktur program pelatihan yang efektif, dinamis dan mendukung program kinerja pelatihan itu sendiri (Baharuddin, 2012). Adapun langkah-langkah dari model pengembangan ADDIE adalah sebagai berikut : 


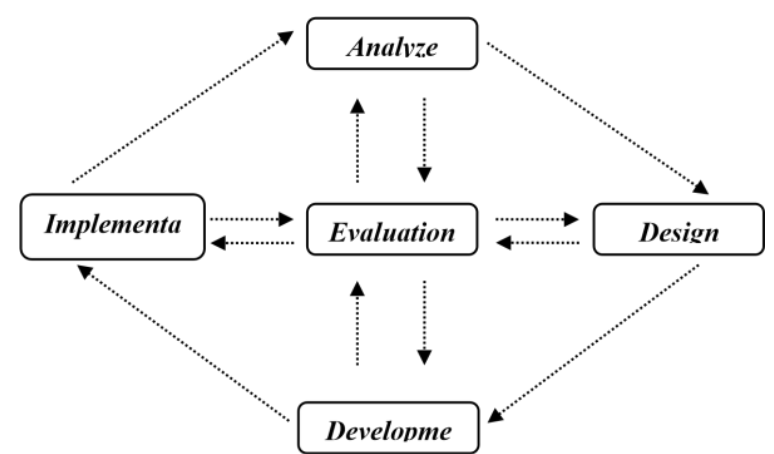

Gambar 2. Tahapan ADDIE Model

Pada tahap analisis, kegiatan utama yang dilakukan adalah menganalisis pengembangan e-modul pada mata pelajaran Pemodelan Perangkat Lunak kelas XI. Pada tahap design peneliti merancang konsep-konsep yang mendasari pengembangan e-modul agar sesuai dengan hasil analisis yang didapat. Tahap ketiga yaitu pengembangan untuk merealisasikan rancangan e-modul yang telah dibuat. Tahap keempat, rancangan yang telah dibuat diimplementasikan dengan menjalankan aplikasi sesuai dengan perangkat lunak dan perangkat keras. Pada tahap akhir yaitu evaluation, evaluasi terhadap e-modul dilakukan agar mengetahui kekurangan dari e-modul tersebut.

\section{A. Uji Coba Produk}

Pada tahap ini pengujian dilakukan oleh para ahli yaitu ahli isi, ahli desain pembelajaran, dan ahli media pembelajaran. Setelah dilakukan revisi dari para ahli, maka selanjutnya akan dilakukan uji coba kepada siswa yaitu uji coba perorangan, uji coba kelompok kecil dan uji coba lapangan.

\section{B. Subjek dan Objek Penelitian}

Subjek penelitian adalah siswa kelas XI program keahlian rekayasa perangkat luna. Subjek uji coba produk hasil pengembangan dosen berspesifikasi $\mathrm{S} 2$, dan guru berspesifikasi S1. Objek dari penelitian ini adalah pengembangan emodul.

\section{Teknik Pengumpulan Data \\ Instrumen yang digunakan untuk mengumpulkan data dalam penelitian pengembangan ini adalah metode}

wawancara dan angket. Metode wawancara digunakan untuk mencari informasi tentang media pembelajaran yang tersedia di sekolah dan menganalisis tujuan serta karakteristik mata pelajaran. Metode angket digunakan untuk mengumpulkan data pada saat menganalisis karakteristik pebelajar dan proses uji coba ahli isi bidang studi, ahli media pembelajaran, ahli desain media pembelajaran, uji perorangan, uji kelompok kecil, dan uji lapangan.

D. Analisis Data

Dalam penelitian pengembangan ini digunakan dua teknik analisis data, yaitu teknik analisis deskriptif kualitatif yang digunakan untuk menganalisis data yang berupa komentar dan saran dari para ahli dan teknik analisis deskriptif kuantitatif yang digunakan untuk menganalisis hasil data angket/kuesioner.

\section{Analisis Kevalidan Modul Ajar}

Validasi e-modul diuji oleh ahli isi, ahli desain, ahli media, uji perorangan dan uji kelompok kecil, menganalisis respon guru dan siswa terhadap pengembangan emodul. Hasil uji ahli dan lembar respon siswa menjadi dasar dan pertimbangan dalam melakukan revisi untuk mendapatkan kesempurnaan e-modul Pemodelan Perangkat Lunak. Pengujian oleh siswa yaitu uji coba perorangan, uji coba kelompok kecil dan uji coba lapangan menggunakan rumus seperti di bawah ini.

$$
\text { Persentase }=\frac{\text { Skor Perolehan }}{\text { SKor Maksimal }} \times 100 \%
$$

\section{Analisis Respon Guru}

Dalam hal ini akan dilakukan validasi terhadap respon guru dalam menggunakan e-modul Pemodelan Perangkat Lunak. Untuk validasi respon guru dilakukan dengan menggunakan angket. Penilaian hasil respon guru dilakukan dengan rumus :

$$
\text { Persentase }=\frac{\text { Skor Perolehan }}{\text { SKor Maksimal }} \times 100 \%
$$

\section{Analisis Respon Siswa}

Validasi respon siswa dilakukan oleh kelas yang sedang mengikuti mata pelajaran Pemodelan Perangkat Lunak untuk mendapatkan respon. Dari kelas tersebut diambil sampel sebanyak 19 orang 
siswa. Penilaian hasil respon siswa dilakukan dengan rumus :

$$
\text { Persentase }=\frac{\text { Skor Perolehan }}{\text { SKor Maksimal }} \times 100 \%
$$

Untuk melihat tingkat pencapaian pengembangan e-modul berdasarkan perhitungan persentase maka ditetapkan kriteria sesuai tabel tingkat pencapaian seperti terlihat pada tabel 1 (Agung, A. G, 2011).

Tabel 1 Konversi Tingkat Pencapaian dengan Skala 5

Tingkat Pencapaian

\begin{tabular}{l}
\hline $90 \%-100 \%$ \\
\hline $75 \%-89 \%$ \\
\hline $65 \%-74 \%$ \\
\hline $55 \%-64 \%$ \\
\hline $0-54 \%$ \\
HASIL DAN PEMBAHASAN
\end{tabular}

Hasil penelitian yang telah dilakukan adalah sebuah e-modul yang valid pada mata pelajaran Pemodelan Perangkat Lunak kelas XI di SMK Negeri 2 Tabanan. Sebuah modul yang valid agar dapat digunakan sebagai sumber belajar oleh siswa maka dilakukan pengujian oleh para ahli maupun siswa. Pengembangan modul ini dilakukan oleh para ahli yaitu ahli isi, ahli desain pembelajaran, dan ahli media. Pengujian terhadap siswa dilakukan melalui uji coba perorangan, uji coba kelompok kecil, dan uji coba lapangan. Setelah didapatkan hasil dari semua uji coba tersebut, angket respon kemudian disebar untuk mengukur keberhasilan $e$ modul Pemodelan Perangkat Lunak kelas XI. Berikut adalah hasil pengembangan e-modul yang telah dibuat.

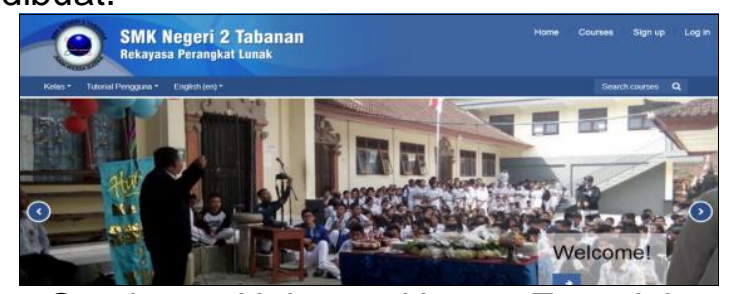

Gambar 3. Halaman Utama E-modul Pemodelan Perangkat Lunak
Kualifikasi

Keterangan

Tidak Perlu Direvisi Tidak Perlu Direvisi

Direvisi

Direvisi

Direvisi

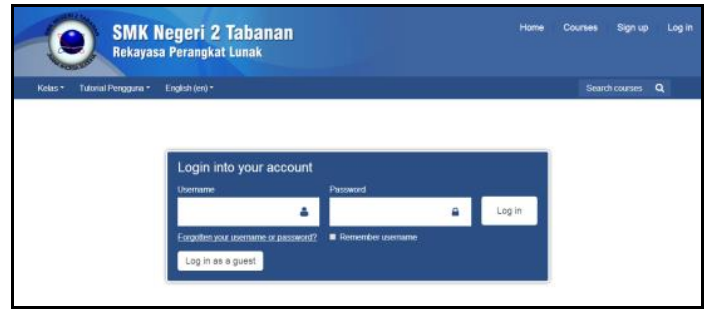

Gambar 4. Halaman Log In

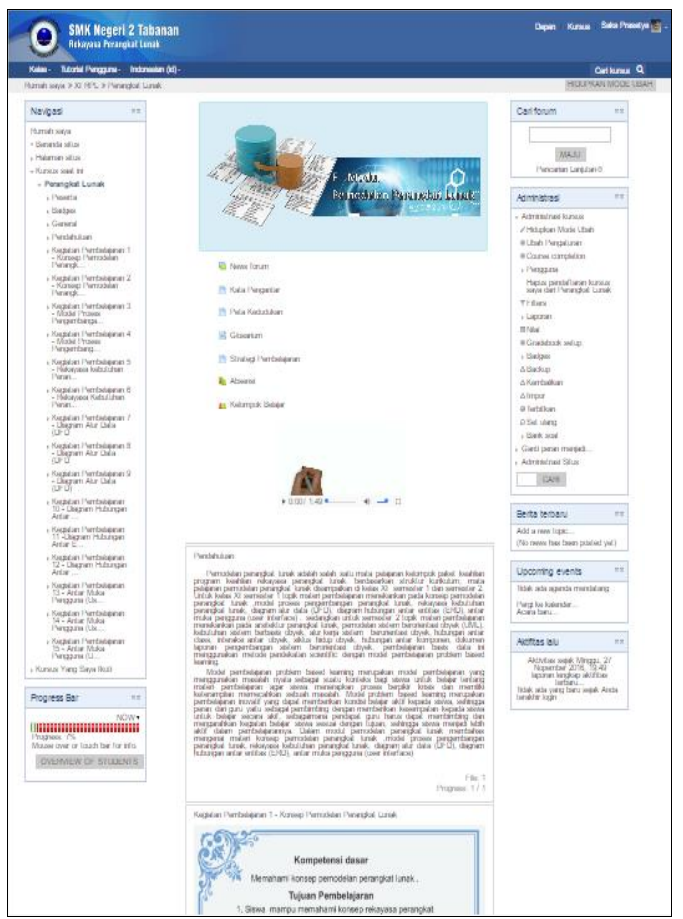

Gambar 5. Halaman Kegiatan Belajar 


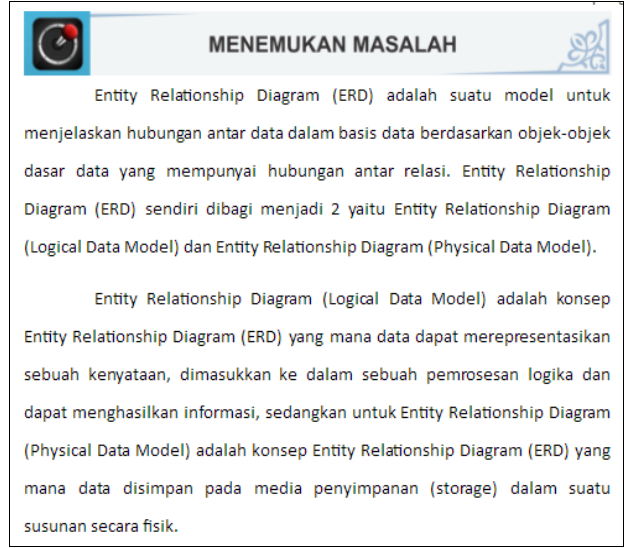

Gambar 6. Halaman Konsep Dasar

Berikut hasil implementasi yang dilakukan adalah sebagai berikut.

Uji ahli isi melibatkan dua orang ahli isi, yaitu Ibu Ni Ketut Eniyawati, S.Kom., M.Kom selaku guru mata pelajaran Pemodelan Perangkat Lunak dan bapak Luh Putu Eka Damayanthi, S.Pd., M.Pd selaku dosen di jurusan Pendidikan Teknik Informatika. Hasil penilaian dari ahli isi dianalisis secara deskriptif berdasarkan masukan dan saran yang diberikan.

Uji ahli desain pembelajaran dalam pengembangan e-modul Pemodelan Perangkat Lunak dengan model Problem Based Learning dilakukan oleh Ibu
Nyoman Sugihartini, S.Pd., M.Pd dan Ibu Ni Made Rai Wisudariani, S.Pd., M.Pd. Ahli desain memberikan penilaian terkait struktururisasi tahap PBL.

Uji validasi media pembelajaran dilakukan oleh Bapak I Made Putrama, S.T., M.Tech dan Bapak I Made Ardwi Pradnyana, S.T.,M.T selaku dosen di jurusan Pendidikan Teknik Informatika. Hasil penilaian dari ahli media dianalisis secara deskriptif berdasarkan masukan dan saran yang diberikan.

Uji coba perorangan dilakukan terhadap 3 (tiga) orang siswa.. Dari hasil penyebaran angket di dapatkan hasil persentase pencapaian e-modul adalah $88,89 \%$ yang termasuk kategori baik sesuai dengn tabel 2 . konversi tingkat pencapaian di bawah ini.

Berdasarkan hasil rekapitulasi dan perhitungan yang memperlihatkan penilaian yang diberikan oleh siswa adalah sangat baik 33,33\%, baik $66,67 \%$, cukup $0 \%$, kurang $0 \%$, dan sangat kurang $0 \%$, dimana jumlah siswa yang memberikan persentase penilaian sangat baik adalah berjumlah 1 orang dan siswa yang memberikan persentase baik berjumlah 2 orang.

Tabel 2. Konversi tingkat pencapaian e-modul

Tingkat Pencapaian

Kualifikasi

Keterangan

\begin{tabular}{lll}
\hline $90 \%-100 \%$ & Sangat Baik & Tidak Perlu Direvisi \\
\hline $75 \%-89 \%$ & Baik & Tidak Perlu Direvisi \\
\hline $65 \%-74 \%$ & Cukup & Direvisi \\
\hline $55 \%-64 \%$ & Kurang & Direvisi \\
\hline $0-54 \%$ & Sangat Kurang & Direvisi
\end{tabular}

Uji coba kelompok kecil dilakukan oleh 12 orang siswa, siswa diberikan untuk mengakses e-modul dan kemudian dilakukan penyebaran angket. Hasil dari penyebaran angket tersebut didapatkan persentase pencapaian e-modul sebesar 87,89\% yang masuk kategori baik. Berdasarkan hasil rekapituasi di dapatkan hasil yang memperlihatkan penilaian yang diberikan oleh siswa adalah sangat baik $58,33 \%$, baik $41,67 \%$, cukup $0 \%$, kurang $0 \%$, dan sangat kurang $0 \%$ dimana jumlah siswa yang memberikan penilaian sangat baik berjumlah 7 orang dan siswa yang memberikan penilaian baik berjumlah 5 orang.

Uji coba lapangan dilakukan oleh 18 orang siswa. Dalam pelaksanaannya e-modul digunakan untuk melakukan proses pembelajaran di dalam kelas oleh guru mata 
pelajaran Pemodelan Perangkat Lunak, kemudian dilakukan penyebaran angket terkait e-modul yang digunakan oleh siswa.Hasil perhitungan angket didapatkan persentase hasil pencapaian sebesar 92,39\% yang termasuk ke dalam kategori sangat baik. Berdasarkan hasil rekapitulasi hasil angket yang memperlihatkan penilaian yang diberikan oleh siswa adalah sangat baik $66,67 \%$, baik $53,33 \%$, cukup $0 \%$, kurang $0 \%$, dan sangat kurang $0 \%$, dimana jumlah siswa yang memberikan penilaian sangat baik berjumlah 10 orang dan memberikan penilaian baik berjumlah 8 orang.

Setelah dilakukan uji coba lapangan, selanjutnya dilakukan uji coba respon siswa yang bertujuan mengetahui respon siswa terhadap $e$ modul yang dikembangkan. Setelah dilakukan penyebaran angket, di dapatkan hasil persentase $62,47 \%$ yang termasuk kategori sangat baik. Berdasarkan hasil rekapitulasi angket respon siswa yang memperlihatkan penilaian yang diberikan oleh siswa adalah sangat baik $84,00 \%$, baik $16,00 \%$, cukup $0 \%$, kurang $0 \%$, dan sangat kurang $0 \%$, dimana jumlah siswa yang memberikan penilaian respon sangat baik berjumlah 16 orang dan siswa yang meberikan respon baik berjumlah 3 orang. Berikut ini dipaparkan grafik perbandingan hasil respon siswa pada gambar 6 .

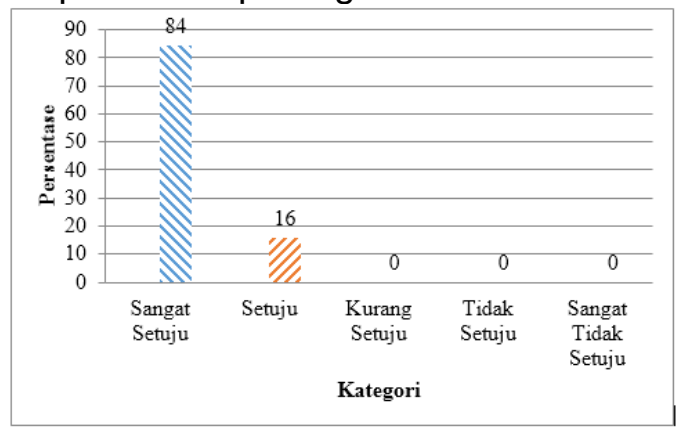

Gambar 7. Grafik Hasil Respon Siswa

Setelah dilakukan penyebaran angket, di dapatkan hasil persentase sebesar $40 \%$ yang termasuk kategori sangat baik. Berdasarkan hasil rekapitulasi perhitungan angket respon guru yang memperlihatkan penilaian yang diberikan oleh guru adalah sangat baik $100 \%$, baik $0 \%$, cukup $0 \%$, kurang $0 \%$, dan sangat kurang $0 \%$, dimana jumlah guru yang memberikan penilaian respon sangat baik berjumlah 1 orang. Berikut ini dipaparkan grafik perbandingan hasil respon guru pada gambar 7.

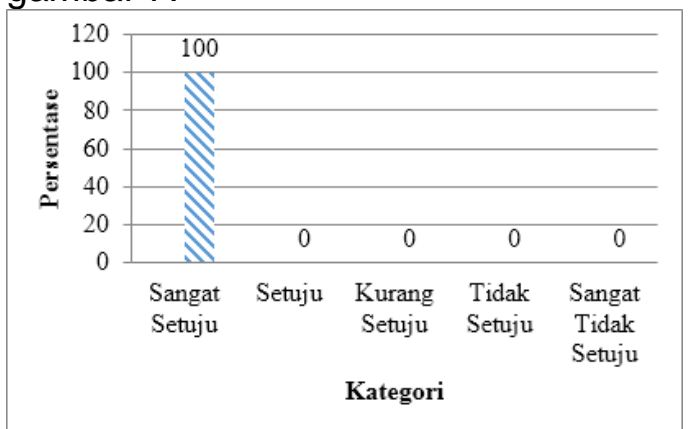

Gambar 8. Grafik Perbandingan Hasil respon Guru

Dengan ini, secara umum mengindikasi bahwa pengembangan $e$ modul mata pelajaran Pemodelan Perangkat Lunak menunjukkan keberhasilan yang dibuktikan dengan terbantunya siswa dalam hal pemerolehan sumber belajar

\section{SIMPULAN}

Berdasakan hasil penelitian dan
pembahasan pada penelitian
pengembangan e-modul pada mata
pelajaran Pemodelan Perangkat Lunak
kelas XI dengan model problem based
learning di SMK Negeri 2 Tabanan,
maka penulis dapat simpulkan
Implementasi e-modul pada mata
pelajaran Pemodelan Perangkat Lunak
kelas XI dengan model problem based
learning di SMK Negeri 2 Tabanan
sudah dinyatakan baik. Hal ini dapat
dilihat dari rata-rata persentase
berdasarkan hasil pengujian yang
dilakukan. Serta respon siswa terhadap
pengembangan e-modul pada mata
pelajaran Pemodelan Perangkat Lunak
kelas XI dengan model problem based
learning di SMK Negeri 2 Tabanan
didapatkan rata-rata persentase
keseluruhan subyek sebesar $62,47 \%$.


Jika dikonversikan kedalam tabel konversi termasuk dalam kategori baik.

Berdasarkan pembahasan

diatas, secara garis besar e-modul pemodelan perangkat lunak

\section{DAFTAR PUSTAKA}

Agung, A. G. 2011. Metode Penelitian Pendidikan: Suatu Pengantar. Singaraja: Fakultas IImu Pendidikan, Universitas Pendidikan Ganesha.

Aunurrahman. (2009). Belajar dan Pembelajaran. Bandung: Alfabeta.

Baharuddin. (2012). Pengembangan Sumber Belajar Berbasis Multimedia Interaktif Pada Mata Diklat Memasang Instalasi Penerangan Listrik. Jurnal Teknologi Pendidikan, 213$221 .$.

Santyasa, I W. 2009. Teori Pengembangan Modul. Singaraja: Universitas Pendidikan Ganesha.

Sugiyono. 2014. Metode penelitian pendidikan pendekatan kuantitatif, kualitatif,dan R\&D. Bandung:Alfabeta

Tatan, Z. (2012). Pengaruh Penggunaan Media Belajar Dan Minat Belajar Terhadap Hasil Belajar Matematika. Jurnal Formatif 1(1), 70-81

Wijayanto, \& Zuhri, M. S. 2014. Pengembangan E-Modul berbasis flip book maker dengan model project based learning untuk mengembangan kemampuan pemecahan masalah matematika. Prosiding Mathematics and Science Forum 2014. Tersedia dalam http://prosiding.upgrismg.ac.id /index.php/masif2014/masif20 14/paper/view/487. Diakses Pada 6 Januari 2016 